\title{
PENGARUH PERAN ORANG TUA TERHADAP MOTIVASI DAN DISIPLIN BELAJAR PESERTA DIDIK SEKOLAH DASAR SELAMA PANDEMI DI WILAYAH PERBATASAN
}

\author{
Winda Lidia Lumbantobing (iD) ${ }^{1)}$ dan Pebria Dheni Purnasari (iD) \\ ${ }^{1,2}$ Pendidikan Guru Sekolah Dasar, Institut Shanti Bhuana \\ 1,2, Jl. Bukit Karmel Sebopet No.1, Suka Bangun, Bengkayang, Kalimantan Barat, 79211 \\ E-mail : winda.tobing@shantibhuana.ac.id ${ }^{1)}$, pebria.dheni@shantibhuana.ac.id ${ }^{2)}$
}

\begin{abstract}
ABSTRAK
Penelitian ini bertujuan untuk mengetahui seberapa pengaruh peran orang tua terhadap motivasi dan disiplin belajar selama pandemi di wilayah perbatasan Kalimantan Barat - Malaysia. Penelitian ini dilakukan melihat perubahan budaya pendidikan yang terjadi akibat pandemi Corona Virus-19. Salah satu perubahan yang terjadi yakni ketika proses pembelajaran peserta didik yang sebelumnya dipantau oleh guru di sekolah, beralih menjadi tugas orang tua dalam memantau proses pembelajaran peserta didik. Peserta didik lebih diharuskan memiliki motivasi dan disiplin belajar agar dapat melangsungkan pembelajaran dengan baik di masa pandemi, secara khusus di peserta didik yang berada di wilayah perbatasan yang memiliki berbagai kendala. Penelitian ini menggunakan penelitian kuantitatif dengan menggunakan metode ex-post facto dan teknik pengumpulan data berupa angket, wawancara dan dokumentasi. Subjek penelitian yang digunakan yaitu siswa sekolah dasar di Bengkayang sebanyak 164 orang peserta didik. Instrumen penelitian sebelum digunakan diuji validasi dengan uji product moment dan diuji reliabilitas menggunakan cronbach alpha. Teknik analisis data yang digunakan adalah teknis analisis data multivariate manova dengan taraf signifikasi $\alpha=0.05$. Uji normalitas dengan menggunakan Kolmogorov Smirnov dan uji Homogenitas varians dengan menggunakan Levene Statistic dilakukan sebelum analisis data. Pengolahan data angket menggunakan IBM SPSS versi 25 for Windows. Hasil penelitian menunjukkan adanya pengaruh signifikan secara simultan antara peran orang tua terhadap motivasi dan disiplin belajar peserta didik dengan nilai Fhitung= 3.650.553 dengan Sig. $=0.000<0.005$.
\end{abstract}

Kata Kunci: Peran Orang Tua, Motivasi Belajar, Disiplin Belajar, Pandemi, Peserta Didik.

\section{PENDAHULUAN}

Indonesia hingga saat ini masih menerapkan pembelajaran jarak jauh dan/atau pembelajaran secara daring sejak dikeluarkannya kebijakan belajar di rumah oleh Menteri pendidikan dengan mengeluarkan surat edaran nomor 36962/MPK.A/HK/2020. Kebijakan tersebut diberlakukan untuk memutus rantai penyebaran corona virus-19. Pembelajaran daring yang ditetapkan pemerintah tidak mengenal jenjang pendidikan, artinya diberlakukan untuk semua jenjang pendidikan dari TK hingga perguruan tinggi. Kebijakan ini secara tidak langsung juga diberlakukan untuk mendukung revolusi 4.0 dengan terlaksananya pembelajaran daring dari rumah, sebab pembelajaran dari merupakan pembelajaran yang mengeliminasi waktu dan jarak dengan bantuan platform digital berbasis internet yang mampu mendukung terlaksananya pembelajaran tanpa terdapat interaksi fisik antara pendidik dan peserta didik (Putra \& Irwansyah dalam Wardani \& Ayriza, 2021) sehingga diharapkan kegiatan pembelajaran daring didukung oleh kemajuan teknologi di zaman saat ini. Akan tetapi, pada jenjang pendidikan sekolah dasar diperlukan peran orang tua secara langsung dalam proses pelaksanaan pembelajaran daring tersebut.
Pada dasarnya, pendidikan anak tidak seharusnya dipercayakan sepenuhnya kepada pihak sekolah, masyarakat dan pemerintah karena keluarga merupakan lingkungan yang paling utama dalam pendidikan tumbuh kembangan anak, baik secara fisik maupun non fisik seperti karakter, penanaman nilai-nilai kehidupan, sosial dan lain sebagainya. Orang tua didorong dapat menciptakan suasana keluarga yang menyenangkan dan harmonis agar anak giat atau disiplin dalam belajar yang pada akhirnya akan mencapai hasil belajar yang optimal. Selain kondisi keluarga yang harmonis, tingkat pendidikan, perhatian serta pemenuhan kebutuhan belajar anaknya juga merupakan tanggung jawab keluarga. Dalam hasil penelitian Hidayati \& Wulandari (2021) menjelaskan peran orang tua yang dilakukan di masa pandemi covid-19 yakni, memberikan motivasi atau penyemangat pada anak, orang tua sebagai fasilitator pada anak dan mengawasi anak dalam belajar. Adanya keterlibatan orang tua menjadi alternatif yang bisa digunakan agar meningkatkan kerja sama pendidik dan orang tua yang secara tidak langsung juga mengoptimalkan peran orang tua (Yulianing., dkk, 2021). Peran orang tua dalam disiplin belajar anak yakni, mengawasi anak dalam belajar supaya anak hendaknya memiliki jadwal belajar khusus bersama dengan orang 
tua, memiliki kebiasaan teratur dalam belajar dan supaya terjalinnya komunikasi antara oran tua dan anak; mengajarkan kemandirian kepada anak untuk mampu dalam menjalankan tanggung jawabnya tanpa bantuan orang lain dan meningkatkan rasa percaya diri; mengenali teknik belajar anak di mana anak akan menolong anak dalam meningkatkan kemauan dalam belajar dan disiplin lagi belajar; menghilangkan kecemasan dan kejenuhan anak dalam belajar karena orang tua tempat anak mencurahkan keluhan yang dirasakan sehingga orang tua dapat memberikan kasih sayang dan rasa aman kepada anak dan orang tua terbuka terhadap anak (Wulandari., dkk, 2017). Begitu juga peran orang tua dalam meningkatkan motivasi belajar anak yang dapat dilakukan menurut hasil penelitian Wahidin (2019) dengan mengetahui hasil belajar anak, memberikan hadiah dan hukuman dan menyediakan alat atau fasilitas yang dibutuhkan. Peran orang tua yang mempunyai semangat tinggi dalam memberikan motivasi belajar dan meningkatkan kemampuan belajar peserta didik akan membawa dampak yang baik bagi anak, apalagi di masa pandemi Covid-19 saat ini peserta didik membutuhkan peran dari orang tua untuk menumbuhkan minat belajar mereka melalui pembelajaran yang akan diajarkan di rumah (Hayati, 2020).

Orang tua dituntut berperan aktif dalam proses pelaksanaan pembelajaran dan peserta didik diharuskan menumbuhkembangkan motivasi dan disiplin belajar dikarenakan pembelajaran daring juga belum pernah dilaksanakan sebelumnya sehingga suasana pembelajaran juga akan sangat berbeda. Seseorang yang memiliki disiplin belajar merupakan seseorang yang memiliki ketaatan terhadap peraturan yang dibuat agar dapat berperilaku tertib dalam belajar. Di sekolah, peserta didik mendapat bimbingan dan arahan dalam pelaksanaan pembelajaran dan juga dibina untuk memiliki karakter-karakter yang baik. Namun, pembelajaran di masa pandemi hal tersebut tidak diperoleh peserta didik secara maksimal dari guru. Peserta didik yang melakukan pembelajaran daring dari tempat tinggal peserta didik mengharuskan orang tua berperan penuh dalam mengawasi dan membina anaknya. Orang tua dituntun dapat mendorong motivasi belajar peserta didik agar tetap melaksanakan pembelajaran dengan maksimal dan dapat menyelesaikan pembelajaran secara daring dengan baik dan juga berperan teguh dalam menumbuhkembangkan disiplin belajar peserta didik agar mengerjakan tugas-tugas dan memahami materi secara konsisten dan tepat waktu.

Namun pada kenyataannya, motivasi dan disiplin belajar peserta didik dalam pembelajaran daring di masa pandemi ini masih cenderung rendah dalam pembelajaran daring. Hasil observasi awal yang dilakukan di beberapa sekolah dasar terhadap guru yang melaksanakan pembelajaran daring mengatakan bahwa peserta didik masih sering mengabaikan tugas-tugas yang harus diselesaikan, tetapi guru-guru berupaya menjalin komunikasi dengan orang tua agar pengerjaan dan pengumpulan tugas dapat berlangsung dengan baik, dan diharapkan peserta didik dapat hadir ketika ada pembelajaran secara daring.

Permasalahan tersebut tentunya dipengaruhi dari berbagai faktor. Salah satunya yang mempengaruhi yaitu faktor peran orang tua peserta didik dalam menumbuhkembangkan motivasi dan disiplin belajar peserta didik keikutsertaan orang tua dalam pendidikan anaknya dengan mencurahkan seluruh pikiran dan perasaan. Oleh karena itu, pentingnya mengetahui besarnya pengaruh peran orang tua terhadap motivasi dan disiplin belajar peserta didik di masa pandemi ini secara khusus di daerah perbatasan.

\section{RUANG LINGKUP}

Berdasarkan latar belakang yang telah dipaparkan, maka rumusan masalah penelitian ini adalah apakah terdapat pengaruh peran orang tua terhadap motivasi dan disiplin belajar peserta didik sekolah dasar terutama di wilayah perbatasan?

Berdasarkan paparan di atas, batasan masalah yang ditetapkan dalam penelitian ini adalah untuk mengetahui seberapa pengaruh peran orang tua terhadap motivasi dan disiplin belajar peserta didik sekolah dasar. Hasil penelitian ini diharapkan akan membantu orang tua, guru maupun pihak sekolah untuk meningkatkan kesadaran setelah nantinya mengetahui bahwa adanya pengaruh peran orang tua dalam motivasi dan kedisiplinan belajar anak terutama pada masa jenjang sekolah dasar yang didukung data empiris secara khusus di wilayah perbatasan Kalimantan Barat - Malaysia.

\section{BAHAN DAN METODE}

Penelitian ini dilakukan dengan menggunakan jenis penelitian kuantitatif dengan menggunakan metode expost facto. Pengumpulan data yang digunakan dalam penelitian ini adalah menggunakan angket dengan skala Likert yang efisien apabila peneliti ingin mengetahui dengan pasti variabel yang akan diukur dan tahu apa yang diharapkan dari responden. Data yang dikumpulkan merupakan data yang telah berlangsung karena penelitian ini tidak diberikan perlakuan tertentu pada variabel bebasnya. Fokus penelitian ini adalah untuk mengetahui pengaruh peran orang tua terhadap motivasi dan disiplin belajar peserta didik di masa pandemi secara simultan. Adapun alur penelitian ini dapat dilihat pada gambar 1 .

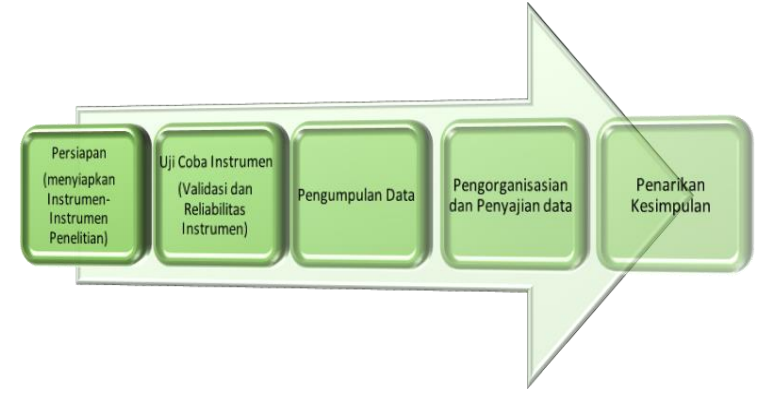

Gambar 1. Alur Penelitian 
Subjek penelitian ini berjumlah 164 peserta didik dengan penggunaan teknik total sampling. Subjek dalam penelitian ini adalah sekolah dasar negeri 2 Bengkayang yang sudah melaksanakan pembelajaran daring dan pembelajaran tatap muka terbatas.

Karakteristik subjek dalam penelitian ini diklasifikasikan berdasarkan tingkat kelas tinggi di jenjang sekolah dasar yaitu kelas IV sampai VI SD dan sudah mampu menggunakan smartphone.

Uji validasi instrumen menggunakan uji product moment dengan perhitungan statistic melalui program SPSS 25.0 For Windows. Butir angket dikatakan valid jika $\mathrm{r}$ hitung lebih besar dari $\mathrm{r}$ tabel ( $\mathrm{r}$ hitung $>\mathrm{r}$ tabel), pada taraf signifikasi 0,05 . $\mathrm{R}$ tabel pada penelitian ini sebesar 0,2213 yang diberikan pada 79 responden. Berikut hasil perhitungan validitas disajikan pada setiap variabel.

\section{Tabel 1. Hasil Validasi Instrumen Peran Orang tua}

\begin{tabular}{|c|c|c|c|}
\hline Variabel & $\begin{array}{c}\text { Butir } \\
\text { Pernyataan }\end{array}$ & r-hitung & Keterangan \\
\hline \multirow{17}{*}{$\begin{array}{c}\text { Peran } \\
\text { Orang } \\
\text { Tua }\end{array}$} & 1 & .527 & Valid \\
\hline & 2 & .718 & Valid \\
\hline & 3 & .575 & Valid \\
\hline & 4 & .384 & Valid \\
\hline & 5 & .310 & Valid \\
\hline & 6 & .728 & Valid \\
\hline & 7 & .626 & Valid \\
\hline & 8 & .610 & Valid \\
\hline & 9 & .584 & Valid \\
\hline & 10 & .497 & Valid \\
\hline & 11 & .481 & Valid \\
\hline & 12 & .285 & Valid \\
\hline & 13 & .655 & Valid \\
\hline & 14 & .708 & Valid \\
\hline & 15 & .721 & Valid \\
\hline & 16 & .594 & Valid \\
\hline & 17 & .683 & Valid \\
\hline \multirow{15}{*}{$\begin{array}{l}\text { Motivasi } \\
\text { Belajar }\end{array}$} & 1 & .163 & Tidak Valid \\
\hline & 2 & .671 & Valid \\
\hline & 3 & .444 & Valid \\
\hline & 4 & .634 & Valid \\
\hline & 5 & .334 & Valid \\
\hline & 6 & .681 & Valid \\
\hline & 7 & .568 & Valid \\
\hline & 8 & .386 & Valid \\
\hline & 9 & .505 & Valid \\
\hline & 10 & .432 & Valid \\
\hline & 11 & .552 & Valid \\
\hline & 12 & .673 & Valid \\
\hline & 13 & .677 & Valid \\
\hline & 14 & .777 & Valid \\
\hline & 15 & .702 & Valid \\
\hline \multirow{7}{*}{$\begin{array}{l}\text { Disiplin } \\
\text { Belajar }\end{array}$} & 1 & .123 & Tidak Valid \\
\hline & 2 & .405 & Valid \\
\hline & 3 & .610 & Valid \\
\hline & 4 & .620 & Valid \\
\hline & 5 & .619 & Valid \\
\hline & 6 & .598 & Valid \\
\hline & 7 & .265 & Valid \\
\hline
\end{tabular}

\begin{tabular}{|c|c|c|c|}
\hline \multirow{4}{*}{} & 8 & .324 & Valid \\
\cline { 2 - 4 } & 9 & .429 & Valid \\
\cline { 2 - 4 } & 10 & .294 & Valid \\
\cline { 2 - 4 } & 11 & .564 & Valid \\
\cline { 2 - 4 } & 12 & .326 & Valid \\
\cline { 2 - 4 } & 13 & .544 & Valid \\
\cline { 2 - 4 } & 14 & .326 & Valid \\
\cline { 2 - 4 } & 15 & .544 & Valid \\
\cline { 2 - 4 } & 16 & .252 & Valid \\
\hline
\end{tabular}

Dari hasil uji coba diketahui bahwa butir angket pada variabel peran orang tua semuanya valid dan pada butir angket pada variabel motivasi dan disiplin belajar yang tidak valid adalah pernyataan nomor 1 . Butir pernyataan yang tidak valid dibuang artinya tidak dapat dipakai dalam penelitian ini. Sehingga jumlah pernyataan yang digunakan dalam penelitian ini berjumlah 17 butir penyataan untuk peran orang tua, 14 butir angket untuk variabel motivasi belajar dan 15 butir angket untuk disiplin belajar.

Uji reliabilitas penelitian ini menggunakan cronbach alpha. Reliabilitas dilakukan untuk menunjukkan bahwa sesuatu instrumen dapat dipercaya untuk digunakan sebagai alat pengumpulan data karena instrumen tersebut sudah baik. Jika nilai koefisien korelasi $\left(r_{\text {alpha }}\right)$ lebih besar atau sama dengan nilai $r_{\text {tabel }}$ pada taraf signifikasi $(\alpha=0,05)$, maka butir pernyataan instrumen dinyatakan reliabel. Sementara, jika nilai koefisien korelasi $r_{\text {alpha }}$ ) lebih kecil atau sama dengan nilai $r_{\text {tabel }}$ pada taraf signifikasi $(\alpha=0,05)$. Berikut hasil uji reliabilitas pada setiap instrument penelitian.

Tabel 2. Uji Reliabilitas

\begin{tabular}{|c|c|c|}
\hline \multirow{2}{*}{ Variabel Penelitian } & \multicolumn{2}{|c|}{ Reliability Statistics } \\
\cline { 2 - 3 } & Cronbach's Alpha & N of Items \\
\hline Peran Orang Tua & .850 & 17 \\
\hline Motivasi Belajar & .811 & 15 \\
\hline Disiplin Belajar & .687 & 13 \\
\hline
\end{tabular}

Hasil analisis menunjukkan nilai cronbach's alpha ketiga variabel penelitian lebih besar dari $r_{\text {tabel }}$ sebesar 0,2213 sehingga dapat disimpulkan reliabel.

Teknik analisis data yang digunakan dalam penelitian ini menggunakan Multivariate analysis of varians (Manova) dengan taraf signifikasi $\alpha=0.05$ yang sebelumnya data yang diperoleh diuji normalitas dan homogenitas nya. Uji normalitas dilakukan untuk melihat data sampel penelitian berasal dari populasi yang terdistribusi normal. Pengujian normalitas dilakukan dengan menggunakan uji Kolmogorov-Smirnov. Berikut hasil uji normalitas penelitian ini.

Tabel 3. Hasil Uji Normalitas

\begin{tabular}{|l|c|c|c|}
\hline \multirow{2}{*}{ Variabel } & \multicolumn{2}{|c|}{ Kolmogorov Smirnov } & \multirow{2}{*}{ Keterangan } \\
\cline { 2 - 3 } & $\mathrm{Z}$ & $\mathrm{Sig}$ & \\
\hline Peran Orang tua & .067 & $.074^{*}$ & Normal \\
\hline Motivasi Belajar & .060 & $.200^{*}$ & Normal \\
\hline Disiplin Belajar & .055 & $.200^{*}$ & Normal \\
\hline
\end{tabular}


Dari hasil uji normalitas di atas, maka dapat dinyatakan seluruh data penelitian ini normal.

Perhitungan uji homogenitas dilakukan dengan Levene Statistic. Varian variabel sama (homogen) jika signifikansi nya lebih besar dari 0.05. Sebaliknya jika signifikan lebih kecil 0.05 maka data varian tidak sama (heterogen). Berikut hasil perhitungan homogenitas penelitian ini.

Tabel 4. Hasil Uji Homogenitas

\begin{tabular}{|c|c|c|c|}
\hline Variabel & Levene Statistic & Asymp sig & Kesimpulan \\
\hline $\begin{array}{c}\text { Motivasi } \\
\text { Belajar }\end{array}$ & 1.513 & .073 & Homogen \\
\hline $\begin{array}{c}\text { Disiplin } \\
\text { Belajar }\end{array}$ & 1.207 & .246 & Homogen \\
\hline
\end{tabular}

Dari data di atas dapat disimpulkan data penelitian ini normal dan homogen sehingga dapat dianalisis.

Pendidikan dalam keluarga dilakukan oleh orang tua supaya anak memiliki karakter yang baik dan tidak terjerumus kepada hal-hal yang tidak benar. Orang tua memiliki peranan yang sangat besar dalam keberhasilan pendidikan anak-anaknya. Orang tua yang menghubungkan dunia anak dengan dunia lainnya, termasuk dunia pendidikannya. Adapun peranan orang tua dalam pendidikan anak adalah sebagai berikut:

1) Pendidik

Orang tua memiliki tanggung jawab penuh dalam mengajarkan dan pengembangan talenta anak serta memaksimalkan seluruh potensi yang dimiliki anak (Lisyani, 2021). Mengetahui dan menolong anak dalam mengatasi kesulitan yang dihadapi anak dan memberikan bimbingan belajar anak sesuai kebutuhan anak perlu dilakukan oleh orang tua.

2) Pendorong atau Motivator

Memberikan motivasi kepada anak dalam mengerjakan tugas sekolah dan belajar, adalah pemberian semangat dari orang tua. Pemberian motivasi ini tidak harus dengan pemberian hadiah kepada anak, melainkan juga bisa dengan pemberian semangat belajar secara lisan dengan perkataan-perkataan positif (Rumbew., dkk, 2018).

3) Fasilitator

Dalam pendidikan anak, orang tua juga bertanggung jawab memenuhi fasilitas belajar anak agar proses belajar dapat berjalan dengan efektif (Wahidin, 2019). Dalam proses pembelajaran anak yang nyaman membutuhkan fasilitas belajar yang nyaman, misalnya seperti ruang belajar, meja, kursi, alat tulis, buku, penerangan yang baik dan lain sebagainya.

Peran orang tua terhadap perkembangan peserta didik tidak dapat diabaikan, peran orang tua sangat penting dalam segala aspek terutama dalam memantau dan memberikan perhatian terhadap pendidikan anak.

Anak yang memiliki motivasi belajar akan terlihat dari kemampuan seseorang dalam memanfaatkan waktu untuk melakukan kegiatan, periode waktu yang digunakan, gairah, keinginan atau harapan yang besar yang berkaitan dengan tujuan, rencana, cita-cita dan sasaran yang hendak dicapai, tingkat pengorbanan pikiran, tenaga dan prioritas yang dilaksanakan dalam menyelesaikan tugas-tugas, ketekunan, ketabahan dan kemampuan dalam menghadapi kesulitan, tingkat inspirasi yang hendak dicapai seperti pencapaian dalam meraih target belajar dan penentuan target, tingkat kualifikasi hasil yang meliputi kesesuaian pelaksanaan belajar dengan hasil belajar, kesesuaian hasil belajar dengan target belajar dan kepuasan terhadap hasil yang ingin dicapai serta dapat dilihat dari arah sikap terhadap sasaran kegiatan yakni kesiapan seseorang untuk terhadap hal-hal yang bersifat positif ataupun negatif (Andriani \& Rasto, 2019). Motivasi belajar dapat timbul karena faktor intrinsik dan faktor ekstrinsik. Faktor intrinsik dapat berupa hasrat dan keinginan belajar, harapan akan cita-cita, sedangkan faktor ekstrinsik berupa adanya apresiasi, penghargaan, lingkungan belajar yang nyaman dan kegiatan belajar yang menarik (Hariyadi \& Darmuki, 2019).

Motivasi belajar yang dimiliki anak akan mendorong kedisiplinan anak dalam belajar. Di dalam disiplin belajar terdapat serangkaian perilaku seseorang yang menunjukkan ketaatan dan kepatuhan pada tata tertib norma kehidupan dan peraturan yang berlaku disebabkan karena adanya dorongan kesadaran dalam diri untuk melakukan tujuan belajar yaitu untuk perubahan perilaku yang diinginkan (Purbiyanto \& Rustiana, 2018). Untuk mendapatkan sebuah perubahan sesuatu dalam mendapatkan sesuatu hasil yang baik diperlukan disiplin dan keteraturan terutama jika menghadapi sesuai kondisi yang berbeda dari sebelumnya misalnya seperti perubahan pembelajaran yang sebelumnya tatap muka menjadi pembelajaran jarak jauh yang diakibatkan pandemi Covid-19. Seorang peserta didik dapat disebutkan memiliki disiplin belajar jika peserta didik masuk kelas pada waktunya, berpakaian sesuai aturan sekolah, menyelesaikan pekerjaan rumah (PR) di rumah bukan di sekolah. Peserta didik akan taat dan patuh pada peraturan sekolah diakibatkan oleh rasa takut kena hukuman atau kesadaran diri sendiri (Wulandari et al., 2017). Namun dalam masa pandemi, dalam pengembangan disiplin belajar peserta didik tidak dapat dikontrol sekolah secara penuh, maka pembinaan yang dilakukan oleh orang tua sangat dibutuhkan dalam membentuk kedisiplinan belajar anak terutama dalam lingkungan keluarga. Peran orang tua dalam mempersiapkan segi perkembangan sosial anak sangatlah penting di mana orang tua menggunakan semua kemampuan yang dimiliki untuk keuntungan mereka sendiri dan untuk segala program yang dijalankan anak, orang tua dan sekolah. Dengan demikian semakin tinggi peran orang tua dalam pendidikan seorang anak dalam mendisiplinkan anak, makan semakin baik pula pendidikan anak tersebut (Nugraheni, 2015) . 


\section{PEMBAHASAN}

Data yang dianalisis menggunakan uji MANOVA untuk mengukur pengaruh variabel independen terhadap beberapa variabel dependen secara simultan atau sekaligus. Uji MANOVA dilakukan dengan membandingkan harga $\mathrm{F}$ untuk Pillae Trace, Wilk Lambda, Hotelling Trace, Roy's Largest, Root.x dengan taraf signifikansi penelitian yaitu sebesar $\alpha=0.05$. Berikut hasil rangkuman uji Manova.

Tabel 5. Hasil Uji Manova

\begin{tabular}{|l|l|l|}
\hline Effect & Sig. \\
\hline \multirow{2}{*}{$\begin{array}{c}\text { Peran orang tua } \\
\text { terhadap motivasi } \\
\text { dan disiplin belajar }\end{array}$} & Pillai's Trace & .001 \\
\cline { 2 - 3 } & Wilks' Lambda & .000 \\
\cline { 2 - 3 } & Hotelling's Trace & .000 \\
\cline { 2 - 3 } & Roy's Largerst Root & .000 \\
\hline
\end{tabular}

Berdasarkan data rangkuman hasil uji hipotesis di atas, dapat disimpulkan bahwa hasil uji hipotesis dengan Multivariate analysis of varians (Manova) diperoleh nilai signifikansi 0,000 . Jadi H0 ditolak karena Sig sebesar $0,001<0,05$. Maka disimpulkan bahwa terdapat pengaruh peran orang tua terhadap motivasi dan disiplin belajar peserta didik secara simultan selama pandemi secara khusus di wilayah perbatasan Kalimantan Barat Malaysia.

Peran orang tua yang diberikan melalui pengajaran dan tuntunan kepada anak, membimbing dan mendampingi anak, memberikan motivasi untuk belajar, dan menyediakan berbagai fasilitas untuk anak dapat mendorong anak melakukan sesuatu dan merasakan kepuasan tentang apa yang sudah dilakukan. Motivasi yang dimiliki merupakan sebagai tindakan-tindakan yang dapat mengubah seseorang atau suatu organisasi tertentu menjadi bergerak untuk melakukan sesuatu karena ingin mewujudkan tujuan yang diharapkan atau dapat memperoleh kepuasan dengan apa yang sudah dilakukannya. Dalam kehidupan manusia memiliki motivasi yang tinggi sangat penting lah terutama dalam diri seseorang yang menempuh jenjang pendidikan, motivasi tertanam dalam diri seseorang yang dapat mendorong seseorang mencapai tujuan yang diinginkan. Hal itu diungkapkan . Motivation is an internal state that arouses, directs, and sustains human behaviour. It plays a fundamental role in learning. Motivasi adalah keadaan internal yang membangkitkan, mengarahkan, dan menopang perilaku manusia. Senada juga dengan pendapat (Moldovan, 2014) yang menyatakan bahwa motivasi mempunyai faktor yang berarti dalam pengontrolan diri, karena mampu menimbulkan efek positif dalam tanggung jawab yang akan dicapai. Dalam peserta didik tujuan yang dicapai tentunya melaksanakan pembelajaran dengan baik. Keseluruhan daya pendorong yang ada pada diri peserta didik yang dapat memunculkan dorongan atau keinginan siswa untuk belajar dikatakan anak miliki motivasi belajar (Priansa, 2015). Berdasarkan hasil wawancara yang dilakukan dengan orang tua dan peserta didik di SD Negeri 2
Bengkayang bahwa peran yang dilakukan orang tua dalam memotivasi dan disiplin belajar anak mereka, orang tua menanyakan setiap pembelajaran yang dilakukan setiap hari, berkomunikasi dengan para wali kelas untuk mengetahui perkembangan anak, kemudian mengontrol jadwal belajar anak secara khusus dalam pengerjaan tugas-tugas sekolah. Orang tua juga terkadang memberikan hadiah seperti membawa anak ke Indomaret atau Alfamart memberi kebebasan kepada anak untuk membeli 1 atau 2 jenis makanan yang mereka hendak sukai sebagai apresiasi jika menyelesaikan tugas. Hal tersebut dilakukan orang tua semenjak anak-anak mereka tidak belajar tatap muka di Sekolah.

Oleh karena itu, peserta didik yang mempunyai motivasi yang kuat akan semakin gigih dan ulet dalam berusaha untuk mempertahankan dan meningkatkan sesuatu yang dilakukan untuk mencapai impiannyaimpiannya yang sudah menjadi tujuan sejak awal. Pada peserta didik sekolah dasar tentunya tujuan awal didorong oleh peran orang tua yang mengarahkan dan membina peserta didik tersebut. Salah satu penggunaan penguatan eksternal yang dapat dilakukan melalui teknik positif seperti memberikan pujian, hak istimewa, dan manfaat meskipun kadang-kadang dengan ancaman dan hukuman dengan tujuan agar motivasi belajar peserta didik terus tumbuh tanpa bermalas-malasan merupakan hal yang sangat perlu untuk dilakukan.

Ciri-ciri seseorang yang memiliki motivasi antara lain: 1) Tekun menghadapi tugas (pentang menyerah sebelum menyelesaikan tugas dengan tuntas); 2) Ulet menghadapi kesulitan (jauh dari rasa putus asa). Pribadi semacam ini tidak lagi membutuhkan dorongan eksternal guna mencapai prestasi (tidak cepat puas dengan prestasi yang telah dicapainya); 3) Tampak memiliki minat dari berbagai macam persoalan; 4) Memiliki sifat individualis dalam menjalankan tugas; 5) Rasa jenuh yang kuat pada tugas bersifat rutinitas (bersifat mekanis, berulang-ulang begitu saja, dianggap kurang kreatif); 6) Keyakinan dan mampu mempertahankan ide temuannya; 7) Menjadi pribadi pemecah masalah di lingkungannya (Sardiman, 2012). Hal tersebut dimiliki oleh peserta didik kelas tinggi di SD Negeri 2 Bengkayang. Peserta didik menanyakan setiap materi yang hendak diketahui dan di masa pandemi peserta didik meminta bantuan kepada orang tua untuk hendak menanyakan ke guru terhadap materi yang disampaikan.

Pada pembelajaran jarak jauh atau yang sering disebut dengan PJJ merupakan pembelajaran yang sangat berbeda dengan pembelajaran tatap muka. Dalam proses pelaksanaan pembelajaran jarak jauh tidak banyak para pendidik yang dapat melaksanakan pembelajaran ini dengan efektif dan efisien akibat berbedanya dengan pembelajaran tata muka yang sering dilakukan. Perbedaan yang paling mendasar tentu peserta didik tidak bisa melakukan interaksi langsung dengan guru (Teguh, 2015). Komunikasi peserta didik dan guru juga sangat terbatas oleh ruang dan waktu. Oleh karena itu, perlunya disiplin belajar yang dituntun oleh orang tua 
agar pembelajaran tetap berlangsung seperti biasanya. Disiplin belajar terlihat dari sikap moral peserta didik yang terbentuk melalui proses dari serangkaian perilaku yang menunjukkan nilai-nilai ketaatan, kepatuhan, keteraturan, dan ketertiban berdasarkan acuan nilai moral yang diwujudkan dalam proses kegiatan belajar. Proses kegiatan pembelajaran jarak jauh yang dilaksanakan di masa pandemi, peserta didik mengumpulkan tugas sesuai dengan yang dijadwalkan guru. Hal tersebut tidak terlepas dari kontrol yang dilakukan oleh orang tua.

Terdapat empat macam disiplin belajar yang dilakukan oleh peserta didik dalam kegiatan belajar yaitu : 1) Disiplin peserta didik masuk sekolah diantaranya, keaktifan, kepatuhan, dan ketaatan dalam masuk sekolah. 2) Disiplin dalam mengerjakan tugas 3) Disiplin dalam mengikuti pelajaran di sekolah, adanya keaktifan, keteraturan, ketentuan, dan ketertiban dalam mengikuti pelajaran yang terarah pada suatu tujuan belajar, 4) Disiplin dalam menaati tata tertib, yakni kesesuaian tindakan peserta didik dengan tata tertib sekolah dengan penuh kesadaran. Hal tersebut memperkuat bahwa orang tua yang berperan aktif dalam tumbuh kembang peserta didik akan berdampak pada disiplin dan motivasi belajar peserta didik.

Semakin tinggi peran orang tua, maka akan semakin tinggi pula motivasi belajar dan kedisiplinan belajar anak. Proses pembelajaran yang saat ini dilaksanakan di rumah menyebabkan peran orang tua sangat dibutuhkan agar tujuan pembelajaran dapat dicapai dengan maksimal (Putri, 2021)

\section{KESIMPULAN}

Peran orang tua melalui pengajaran dan tuntunan kepada anak, membimbing dan mendampingi pembelajaran anak terutama dalam keteraturan dalam waktu belajar, memberikan motivasi untuk belajar, dan menyediakan berbagai fasilitas untuk anak dapat mendorong anak melakukan sesuatu dan merasakan kepuasan tentang apa yang sudah dilakukan anak terutama pada anak jenjang sekolah dasar. Dengan terdapatnya pengaruh yang signifikan antara peran orang tua terhadap motivasi dan disiplin belajar peserta didik pada jenjang sekolah dasar di masa pandemi ini, terlihat jelas peran orang tua sangat dibutuhkan dalam meningkatkan motivasi dan disiplin belajar terutama pada jenjang sekolah dasar.

\section{SARAN}

Dalam meningkatkan motivasi belajar dan disiplin belajar anak dibutuhkan peningkatan peran orang tua dalam pendampingan belajar orang tua. Orang tua perlu memantau perkembangan belajar anak dan dapat berdiskusi dengan guru dalam mengevaluasi bahkan berkolaborasi dalam meningkatkan motivasi dan disiplin belajar anak sekolah dasar terutama pada masa pandemi saat ini. Para guru dan lembaga masyarakat juga perlu adanya juga pemaparan hasil penelitian terkait peran orang tua dalam pendidikan anak secara langsung agar orang tua semakin terpacu dalam melibatkan diri dalam perkembangan anak secara optimal.

\section{DAFTAR PUSTAKA}

Andriani, R., \& Rasto. (2019). Motivasi belajar sebagai determinan hasil belajar siswa. Jurnal Pendidikan Manajemen Perkantoran, 4(1), 80. https://doi.org/10.17509/jpm.v4i1.14958

Hariyadi, A., \& Darmuki, A. (2019). Prestasi dan motivasi belajar dengan konsep diri. Prosiding Seminar Nasional, ISBN: 978-, 280-186.

Hayati, A. S. (2020). Peran Orang Tua dalam Meningkatkan Motivasi Belajar Anak Dengan Sistem Daring pada Masa Pandemi di Desa Depokrejo , Kebumen Arifia Sabila Hayati. Jurnal Tasyri', 2, 23-32.

Hidayati, N., \& Wulandari, I. (2021). Peran Orang Tua Dalam Mendukung Kegiatan Pembelajaran Anak SMP Di Rumah Pada Masa Pandemi Covid-19 di Desa Kumpulrejo Kecamatan Parengan Kabupaten Tuban Tahun Pelajaran 2020/2021. Journal of Islamic Elementary Education, 3(1), 57-77.

Lisyani, L. (2021). Peran Orang tua dalam Mendampingi Pembelajaran di Masa Pandemi Covid-19 pada PAUD Tarbiyatul Aulad. Jurnal Syntax Transformation, 2(8), 1125-1129.

Moldovan, O. D. (2014). Intrinsic and Extrinsic Motivation to Primary School Children. Journal Plus Education, 5(1), 203-211.

Nugraheni, R. K. (2015). Pengaruh Peran Orangtua Motivasi Belajar dan Lingkungan Keluarga terhadap Prestasi Belajar Siswa Kelas III SD SeGugus Sinduharjo Sleman Tahun Ajaran 2014/2015. http://repository.upy.ac.id/138/.

Priansa, D. J. (2015). Manajemen peserta didik dan model pembelajaran cerdas, kreatif, dan inovatif. Alfabeta.

Purbiyanto, R., \& Rustiana, A. (2018). Pengaruh Disiplin Belajar, Lingkungan Keluarga dan Motivasi Belajar terhadap Hasil Belajar Siswa. Economic Education Analysis Journal, 7(1), 279-285.

Putri, D. M. (2021). Pengaruh Peran Orangtua Terhadap Motivasi dan Kedisiplinan Belajar Anak Sebagai Dampak Wabah Covid-19. Jurnal Paradigma, 11(1), 109-144.

Rumbewas, S. S., Laka, B. M., \& Meokbun, N. (2018). Peran Orang Tua Dalam Miningkatkan Motivasi Belajar Peserta Didik di Sd Negeri Saribi. Jurnal EduMatSains, 2(2), 201-212.

Sardiman. (2012). Interaksi dan Motivasi belajar mengajar. Raja Grafindo Persada.

Teguh, M. (2015). Difusi Inovasi Dalam Program Pembelajaran Jarak Jauh Di Yayasan Trampil Indonesia. Scriptura, 5(2), 71-78. https://doi.org/10.9744/scriptura.5.2.71-78

Wahidin. (2019). Peran Orang Tua Dalam Menumbuhkan Motivasi Belajar Pada Anak Sekolah Dasar Wahidin*. 3(1), 232-245. 
Wardani, A., \& Ayriza, Y. (2021). Analisis Kendala Orang Tua dalam Mendampingi Anak Belajar di Rumah Pada Masa Pandemi Covid-19. Jurnal Obsesi : Jurnal Pendidikan Anak Usia Dini, 5(1), 772. https://doi.org/10.31004/obsesi.v5i1.705

Wulandari, W., Zikra, \& Yusri. (2017). Peran Orangtua dalam Disiplin Belajar Siswa. 2(1), 24-31.

Yulianingsih, W., Suhanadji, S., Nugroho, R., \& Mustakim, M. (2021). Keterlibatan Orangtua dalam Pendampingan Belajar Anak selama Masa Pandemi Covid-19. Jurnal Obsesi: Jurnal Pendidikan Anak Usia Dini, 5(2), 1138-1150. https://doi.org/10.31004/obsesi.v5i2.740

\section{UCAPAN TERIMA KASIH}

Seluruh peneliti menyampaikan rasa terima kasih sedalam-dalamnya kepada pihak perguruan tinggi Institut Shanti Bhuana yang telah membiayai seluruh penelitian, dengan nomor kontrak penelitian:

1180/ISB/PRPM/IN03/2021. Kami juga berterima kasih kepada seluruh pihak sekolah baik kepala sekolah, guru maupun staff serta peserta didik dan orang tua yang telah mendukung penelitian ini baik dalam memberikan dukungan moral, waktu dan izin sehingga program penelitian ini dapat terselesaikan. 